\title{
A Cognitive-Developmental Approach for Coach Development
}

\author{
Tatiana Bachkirova, Faculty of Business, Oxford Brookes University \\ Elaine Cox, Faculty of Business, Oxford Brookes University
}

Coach training courses and postgraduate courses for coaches and coaching psychologists have grown in number very considerably during the last decade. We are now more aware how important a role the self of the coach plays in their coaching practice. It is also widely accepted that not only relevant knowledge but also psychological development of coaches is of paramount importance in the process of becoming a coach. A number of theories that address the nuances of developmental processes in adulthood have become better known in the coaching field and accepted as helpful for working with clients. However, very few authors write about developmental benchmarks for coaches and coaching psychologists. In this chapter, we consider existing theories of individual development and suggest a developmental framework for coaches based on these theories that can be used in the context of coach education and training.

The developmental perspective implies that adults are not unchanging, but are continually learning, developing and growing. In this chapter, we adopt the following definition: development is "a combination of changes in the organism manifested in a sustained increased capacity of the person to engage with and to influence their environment and to look after their internal needs and aspirations" (Bachkirova, 2011: 4). In line with this view the purpose of this chapter is to present a description of developmental tasks for coaches, based on a synthesis of models of cognitive development and ego development. The chapter is divided into a number of sections:

- First, we outline the theoretical background that underpins a number of models of adult development (Kohlberg, 1969, Perry, 1970, King \& Kitchener, 1994, Kegan,1982, 1994, Cook-Greuter, 2004, Bachkirova, 2011)

- Second, we discuss recent applications of these theories to coach, coaching psychologist or mentor development (Berger, 2006, 2012, Chandler and Kram, 2005, Bachkirova, 2011, 2013).

- Third, the chapter provides a model developed by us that could be appropriate for use in development programmes for coaches or coaching psychologists, or could provide a reference point during coaching supervision.

- Finally, a case study is presented to provide a flavour of how the theories and the model might inform a supervision relationship.

\section{Theoretical Background}

Although a relatively young theory, cognitive-developmentalism (also called structuralism or constructivism), already has a distinct place and role in explaining behaviour. It also brings an important and clearly defined dimension to understanding the development of individuals. All cognitive-developmental theories, consider how human beings think and make meaning and are fundamentally structured. The structures themselves (e.g. schema (Piaget), subject-object relation (Kegan)) are seen as permanent or changing very slowly. Each person constructs his/her own frameworks according to his/her specific combination of external circumstances and internal factors. Where other traditions and schools of psychology are looking for common features of change in development of individuals and for specific conditions for facilitating this change, cognitive developmentalists identify 
patterns indicating qualitative shifts in the potential process of development itself and suggest ways of applying this knowledge to each individual.

Developmentalists view that the process of change in individuals occurs in different ways, dimensions and at different rates, and not only through changes in their structures. People learn new skills, acquire new knowledge and change their personal qualities throughout their life in different ways and by very different means. However, the changes that are addressed by developmentalists are much rarer. They signify significant shifts in the way an individual sees the world and interprets his/her experiences. They influence the depth and complexity of what he/she can notice, representing a level of change that could be seen as vertical rather than horizontal (Cook-Greuter, 2004). In addition, the latest development in the field of adult development indicates that it is possible to recognise developmental shifts in adults' engagement in action which could be illustrated by a different relationship between mind and body in the control of action (Bachkirova, 2011).

Fully developed cognitive-developmental theories see human potential as changing from simple, static and ego-centric to complex, dynamic and world-centric. The qualities of each stage of development, when transcended to reach the next level, remain as properties of the new stage. The person can utilise any skill that he/she learned before and with each stage is becoming more flexible, integrated and therefore more capable of functioning in the world that is also changing and becoming more complex.

What is particularly important in relation to the development of coaches is that each stage enriches individual capacity for reflection and effective interaction with others and with tasks. Their ability to notice nuances and details of situations is increasing. The resultant self-awareness gives them a better opportunity to articulate, influence and potentially change these situations. Their capacity to understand others at earlier stages is increasing with each new stage they reach. However there is always scope and potential for further development at whatever stage the individual operates. The development process is an outcome of a combination of internal and external factors for each individual, but can also be further stimulated and facilitated by appropriate support and challenge within the coaching process.

We believe that the cognitive-developmental perspective is very important for understanding factors influencing changes in coaching process. It is also particularly useful for understanding development of the coach and growth of their capacity for helping others to develop. In this chapter we explore cognitive-developmental theories from two perspectives that we believe are most significant for development of coaches and coaching psychologists. We call the first perspective the cognitivereflective strand, which has its origins in Piaget's work and emphasises reasoning and learning capacities (specific examples include: Kohlberg, 1969, Perry, 1970, King and Kitchener, 1994). The second perspective is the ego-development strand, with its origins in Loevinger, which focuses on the development of self-identity, maturity of interpersonal relationships and engagement in action (specifically Kegan, 1982 and 1994; Cook-Greuter 2004; Bachkirova, 2011).

\section{$\underline{\text { Cognitive-reflective strand }}$}

Piaget is generally considered the founding figure in developmental psychology. His (1976) model of cognitive development presents ordered stages through which children develop. Piaget reasons that development occurs when a child's current cognitive structures can no longer reconcile conflicts between existing understanding and current experience of the world. At this point some cognitive restructuring is 
necessary, resulting in progression towards a more sophisticated level of development. The development culminates in early adolescence with the development of abstract reasoning at the 'formal operations' stage.

Other theorists have since worked to extend stage theory beyond the Piagetian 'formal' arena, identifying limitations in formal operations and describing the kind of thinking that enables individuals to transcend these limitations into 'postformal' stages (Commons \& Richards, 2002). Koplowitz (1984) for example, incorporates Piaget's concrete operations and formal operations stages, but goes beyond this to posit a post-logical or system thinking stage followed by a fourth stage of unitary operational thought.

Perry's (1970) model of intellectual and moral development also broadens Piaget's framework adding an element of responsibility. Perry suggested there are structural changes in a person's assumptions about the origins of knowledge and value and describes three overlapping phases of development that encompass nine cognitive positions. His empirical research with college students identifies three phases of development that move from basic duality in thinking at position 1, through a growing awareness of multiplicity and relational knowing at position 5 , to more contextual relativism, commitment and resolution at the more developed positions, 8 and 9 . Perry points out that possibly the most difficult transition is the shift from simple dualism to complex dualism.

Perry's findings also inspired Belenky et al. (1986) to explore women's ways of knowing. In their categorisation, Perry's dualist phase was called 'subjectivist', whilst the move towards relativism was referred to as 'separate knowing':

"subjectivists assume that everyone is right, separate knowers, on the other hand, are especially suspicious of ideas that feel right" (p.104).

Also building on Perry's work, King \& Kitchener (1994) developed a model of reflective judgement. They described how educators need to engage students meaningfully in addressing ill-structured problems, i.e. problems where a solution cannot be described with any degree of certainty or completeness. They suggested that development spans seven stages (King \& Kitchener,1994, p.11-12):

Stage $1 \quad$ Knowing is limited to single concrete observations

Stage 2 There are two categories for knowing: right answers and wrong answers

Stage 3 In some areas, knowledge is certain, whilst in others knowledge is temporarily uncertain.

Stage 4 Since knowledge is unknown in some specific cases, all knowledge is uncertain

Stage $5 \quad$ Knowledge is uncertain and so must be understood within a context

Stage 6 Because it is contextual, knowledge is constructed by comparing evidence and opinion

Stage $7 \quad$ Knowledge is the outcome of a process of reasonable inquiry towards a general principle that is consistent across domains. 
King and Kitchener (1994) go on to highlight two main differences between their model and other contemporary models of cognitive development. The first is that epistemic assumptions are important to the reasoning process. The second difference endorses Dewey's (1991) assertion that true reflective thinking is uncalled for unless real uncertainty exists about the possible solution to the problem.

Some authors have argued that the stage of cognitive development that enables people to examine rationally the assumptions and values by which they justify their beliefs, takes place only in late adolescence or adulthood (Brookfield, 1987; Garrison, 1991; Mezirow et al, 1990). They argue that the ability to reflect critically happens not just as a function of physical maturity but because as people get older their reasoning and reflective capacities develop due to the challenging experiences and encounters that occur over time. Mezirow in particular, argues that it is only through transformative learning that changes in psycho-social development can occur and that it is a key role of the adult educator to help to facilitate such learning:

"The adult educator actively precipitates transformative learning when, in the process of helping learners address their expressed needs, he or she seeks to move the learners' interest beyond their articulated needs to understanding the reasons for them and the way that psycho-cultural forces have shaped the learners' interpretation of the worlds of others, and of themselves" (1990, p. 365, our emphasis).

Kohlberg's (1969) model also has relevance for our brief overview of the origins of cognitive theory. Kohlberg used stories about moral dilemmas to explore how respondents explained their actions. Responses were classified into three levels (pre-conventional, conventional and post-conventional) and within each level there were two stages. Kohlberg found that the men he studied were not able to understand moral reasoning more than one stage ahead of their own: a person in Stage 1 could understand Stage 2 reasoning but nothing beyond that. This suggests that in learning situations only moral arguments that are one stage ahead of the person's present level of reasoning should be introduced in order to maximise movement to higher stages. Gowan (1974) also cautions against "developmental abuse", suggesting that this occurs when the use of characteristics of a higher stage are encouraged whilst the individual is coping with the tasks of an earlier stage.

Gowan's work however, moved away from delineating stages of cognitive development and focused on the developmental process as a continuum that includes but transcends the dimensions of cognition, affect, rational and emotional development (see Miller, 2012). In the next section we explore this notion of ego transcendence in further detail.

\section{Ego development strand}

The term of ego-development was introduced to the field of cognitive-developmental psychology by Loevinger (1976). Using a psychometric method that was geared to accentuate individual differences, she identified a new variable. The variable was closely associated with a factor earlier studied by Sullivan and associates (1957), which they called interpersonal maturity or the capacity for interpersonal integration. Loevinger (1987) writes that although she was hesitant about using this term because of its specific association with the psychoanalytic concept restricted to the first years of a child's life, no other terms were inclusive enough to describe the phenomena that she identified. Loevinger also assumed a basic stage structure that was consistently identified. Each person in her study was progressing from one stage 
to the next as the result of his or her own pattern of interests and social circumstances. Specific stages in the development of self-identity with a corresponding interpersonal mode include:

Impulsive

Self-protective

Conformist

Conscientious-conformist

Conscientious

Individualistic

Autonomous

Integrated
Egocentric, dependent

Manipulative, wary

Cooperative, loyal

Helpful, self-aware

Intense, responsible

Mutual

Interdependent

Cherishing individuality

(Loevinger;1987, p. 226)

The next theory that well represents the strand of ego development is Kegan's (1982) orders of consciousness. The theory addresses two fundamental human processes: integration as movement towards relatedness and inclusion and differentiation as movement towards separation and autonomy. Meaning making activity for Kegan revolves around what one takes to be self and what one takes to be other and what the relationship is between them. This 'Subject-Object' relations framework, illustrates how individuals grow, like the dynamics of a balancing act, maintaining and then breaking out from the equilibrium between self and other.

Things that are Subject in this theory are by definition experienced as unquestioned, simply a part of the self. They cannot be seen because they are a part of the individual. Thus they cannot be reflected upon as that would require the ability to stand back and take a look at them. While things that are Subject have us in this way, we have things that are Object. Things that are Object in our lives are "those elements of our knowing or organizing that we can reflect on, handle, look at, be responsible for, relate to each other, take control of, internalise, assimilate, or otherwise operate upon" (Kegan, 1994, p. 32). The more individuals can take as Object, the more complex their world view becomes, because they can examine and act upon more things.

The idea of development in Kegan's theory is best understood through the following analogy: To be subject is to "see with" rather than to "see through". Drath (1990, p. 486) describing this theory gives a good example of 'cultural blindness': "We see with our culture-bound norms and expectations, accept them as given, and cannot examine them for what they are - that is, we cannot see through them. Our cultural heritage is something we are, not something we have. The culture holds us; we are embedded in it and cannot rise above it". In some circumstances, however, and with further growth we may become aware of differences that are culturally determined and become aware of the distance from others in a way that we never did before.

Kegan describes six stages (Orders of Mind) through which people evolve, with three that are more applicable to adults and potential coaching clients:

1. The Interpersonal stage describes a person who has needs, not is her needs, so others are understood as also having needs. They are no longer a means to his/her ends. But people at this stage still are their relationship. They are self-reflective and can subordinate their needs to something greater, but they feel torn apart by the conflict between important others. They have no sense of what they want outside of the expectations of others. This causes both difficulties in making decisions and issues of self-esteem, because people at 
this stage need other people to like them. They can do anything as long as they have someone whom they respect and who can help them make decisions.

2. The Institutional stage suggests that the person is someone who now has the relationship. This creates a self that exists even outside of relationship to others, and has a sense of autonomy and identity. People at this stage are able to examine various rules and opinions and mediate between them. Unlike those at the Imperial stage they feel empathy for others and take their view into consideration. Unlike those who are at the Interpersonal stage they are not torn apart by others' views - they have their own system with which to make decisions. They are self-motivated, self-evaluative and can make good leaders. They can create their own rules and fight for them but may be not be the best diplomats, because they are too invested in their own way of doing things.

3. At the Interindividual stage a person becomes someone who has identity, so becomes individual. They have achieved everything available to the previous stage, but in addition have learned the limitations of their own inner system and the limitation of having an inner system in general. They can look across their inner system and see similarities in what look like differences. They have less dichotomies and polarities and are less prone to black and white thinking. They could act as wise advisors to anyone and help others to understand that we are all member of larger community.

In developing her recent theory of Developmental Coaching, Bachkirova (2011) proposed another aspect of ego development particularly important for coaching that aims to make contribution to the individual's engagement in action. Three stages of development in relation to this criterion were offered as shown in Table 1:

\begin{tabular}{|c|c|c|c|}
\hline & Unformed ego & Formed ego & Reformed ego \\
\hline $\begin{array}{l}\text { Engagement in } \\
\text { action } \\
\text { (Bachkirova, } \\
\text { 2011) }\end{array}$ & $\begin{array}{l}\text { Reduced sense of } \\
\text { control over } \\
\text { themselves and } \\
\text { environment. } \\
\text { Higher dependency } \\
\text { on others for action. }\end{array}$ & $\begin{array}{l}\text { Capacity to take } \\
\text { ownership of the } \\
\text { past and act } \\
\text { independently. } \\
\text { 'Mind over body' } \\
\text { control of action. }\end{array}$ & $\begin{array}{l}\text { Harmony between } \\
\text { mind and body in } \\
\text { action. Appreciation } \\
\text { of complexity in the } \\
\text { relationship between } \\
\text { self and } \\
\text { environment. }\end{array}$ \\
\hline
\end{tabular}

Table 1: Three stages of development for engagement in action

Bachkirova (2011) argues that this dimension draws the attention of the practitioner to an element of the client's self that is particularly important in coaching where action is seen as constituent of change and development. The ego would be considered as fully developed (formed) in this respect if the person can act or refrain from action if necessary in a way that reasonably satisfies the organism as a whole. There is an ability to take ownership of the past, withstand anxiety about what the future holds and build relationships with others without losing the sense of the self. However, the sense of control and self-ownership may lead to an overestimation of what is possible and realistic for the organism. With the unformed ego there are needs that remain unsatisfied and tasks unfulfilled and there is a legitimate need for more help or guidance from others. The third category, the reformed ego, represents capacities of the ego that go beyond those of the formed ego. There is a much more harmonious relationship between the mind and body, conscious and unconscious and it is manifested in the ability of the organism to tolerate the ambiguity of some 
needs and tasks and minimise the waste of energy on internal conflicts (Bachkirova, 2011).

\section{Applications of the theories to Coaching}

Cognitive-developmental theories are already successfully applied to various areas of practice. There are currently several authors who write about the application of cognitive-developmental approaches in relation to coaching and mentoring and offer their perspectives and models. For example, Rooke and Torbert (2005) in collaboration with Cook-Greuter created a survey tool, the Leadership Development Profile, that allows identification of what they call leaders' internal 'action logic'.

Seven different action logics were identified that illustrate the ways individual leaders interpret their situation, respond to challenges and tend to influence others. Rooke and Torbert argue for the importance for leaders to know their action logic, to evaluate their strengths and limitations in relation to current circumstances and to identify potential for further development.

Berger (2012), building on Kegan (1982), offers a description of four forms of mind in the context of changing on the job. Each mode results in different ways of perspective taking, orientations to authority and rules, key needs in relationship with others and assumptions about the world. Berger's forms of mind correspond to four levels of development: Self-sovereign, Socialized, Self-authored and Selftransforming. One of her most valuable contributions is that she identifies not only key strengths, blind spots and areas of growth for each of these groups but also suggests potentially useful interventions for coaching and leaders and considers pitfalls that coaches may face when working with each group. We also find ourselves in congruence with Berger's position on the role of assessment, considerations of ethical issues for coaches when engaged with the developmental approach and her emphasis on "simply listening for our client's growth edge" (2012, p. 94, emphasis in original). We also noted that learning about developmental theories for coaches is developmental in itself.

Chandler and Kram (2005, p.549), relate adult development perspectives to other developmental networks and relationships, such as mentoring. Their contention is that "protégés at different stages will maximally benefit from developers at higher stages, given that they will have transcended the limitations that the protégé faces". To support this argument, Chandler and Kram examine Kegan's stages in relation to the tasks of the protégé and the mentor. Chandler and Kram also identify how a variety of instruments and methods have been devised to assess developmental stages. Lahey and associates (1988) developed the subject-object interview, whilst the Washington University Sentence Completion Test is used to measure Loevinger's (1976) stages.

However, we suggest that any progress with applications of developmental theories is impeded by the complexity of using very labour intensive instruments for assessment of stages. The use of these instruments requires not only sophisticated training but also a high level of development of the assessors themselves. Another issue concerns the intention to achieve precision when these instruments are used. We believe that precision is not necessary for developmental coaching to be successful. For example, there are factors that interfere with the quality of measurement such as verbal fluency and educational and social background (McCauley et al, 2006; Manners \& Durkin, 2001). There is also a limitation of each individual theory being focused on one particular developmental line (Wilber 2000). However, actual coaching assignments are more complex and multifaceted. When coaches encounter an individual client, they may need to work with a variety of themes such as 
interpersonal, cognitive, emotional, etc. This work should involve addressing each area of development with an open mind in spite of the indication of a particular stage in some of the others (Bachkirova, 2011, 2013).

Considering the above concerns Bachkirova (2011) suggested a practical application of a developmental framework that is based not on measurement instruments, but on evaluation of developmental themes which by themselves indicate one of the three stages of development. It was argued that the intentions and goals that clients bring to coaching can show a pattern that is developmental. These themes are about the challenges that people face in life, what they find difficult, and what their life circumstances demand from them. The pattern in the themes would indicate the stage of the ego in each client and help to shape an individual approach to coaching.

\section{Our model of Coaches Cognitive and Ego Development}

It has been shown that particularly the ego developmental perspective could provide important dimensions for understanding the human development. In this section we propose to extend the application of this developmental perspective to enhance understanding of the developmental process of coaches and coaching psychologists. The model of coach development that we suggest is informed by the earlier discussed theories.

In our practice of facilitating the personal and professional development of coaches, we observed how various aspects of the style, attitudes and behaviours of coaches in the process of learning can indicate stages of their individual development. From an analysis of our observations we identified two specific developmental dimensions, a combination of which in our view affects the qualitative changes in coaches' personal style and expertise that can signify a stage in their overall development:

1. The cognitive-reflective dimension describes the degree of the complexity of thought and reflective judgment as described by Perry, Kohlberg, King and Kitchener.

2. The ego-development dimension describes intrapersonal and interpersonal aspects of development indicating ego-development, degree of openness, authenticity and inclusiveness of others as described by Kegan, Loevinger and Cook-Greuter.

We consider these two dimensions as most influential. In combination they represent different aspects of coaches' philosophies of relationship and individual development, reflexivity, role of ego in motivation and actions, style of working with clients and attitude to problems and challenges. We believe that these two dimensions are equally important for indicating the overall stage of coach development. They are therefore presented jointly in the following 6-level model of coach development (Table 2). 
INSERT TABLE 2 HERE

\begin{tabular}{|c|c|c|c|}
\hline $\begin{array}{c}\text { Stage of } \\
\text { development }\end{array}$ & $\begin{array}{c}\text { Cognitive-reflective } \\
\text { dimension } \\
+ \\
\text { Ego development dimensions }\end{array}$ & $\begin{array}{l}\text { Coaches typical } \\
\text { pattern of working } \\
\text { with coaching clients }\end{array}$ & $\begin{array}{l}\text { Developmental tasks } \\
\text { that coach could be } \\
\text { effective in facilitating }\end{array}$ \\
\hline The Teller & $\begin{array}{l}\text { Polar thinking; concrete data; } \\
\text { prescribed models; received } \\
\text { knowing }\end{array}$ & $\begin{array}{l}\text { Take sides; give lots of } \\
\text { advice on the basis of } \\
\text { their own experience } \\
\text { and preferences }\end{array}$ & $\begin{array}{l}\text { Development of self- } \\
\text { image and } \\
\text { reputation; support in a } \\
\text { competitive } \\
\text { environment }\end{array}$ \\
\hline The Helper & $\begin{array}{l}\text { Abstract thought; careful } \\
\text { comparisons; reliance on } \\
\text { internalised systems and } \\
\text { intuition; subjective knowing } \\
\text { Self-conscious; group-oriented } \\
\text { but realising their specialness; } \\
\text { strong internalized super-ego; } \\
\text { high moral standards and } \\
\text { sense of duty; critical of others, } \\
\text { but able to build good } \\
\text { relationship }\end{array}$ & $\begin{array}{l}\text { Give emotional support; } \\
\text { help to investigate } \\
\text { situation in order to } \\
\text { 'figure it out'; heavy } \\
\text { reliance on } \\
\text { psychometric tools; } \\
\text { offer own } \\
\text { interpretations of } \\
\text { situations; generate } \\
\text { various solutions to } \\
\text { problems }\end{array}$ & $\begin{array}{l}\text { Developing confidence; } \\
\text { learning new skills; } \\
\text { dealing with concrete } \\
\text { problems; adjustment } \\
\text { to difficult situations }\end{array}$ \\
\hline $\begin{array}{l}\text { The } \\
\text { Questioner }\end{array}$ & $\begin{array}{l}\text { Multiplicity and patterns; clear } \\
\text { separation of knower and the } \\
\text { known; critical evaluation; } \\
\text { rational and analytical; going } \\
\text { beyond subjectivism; } \\
\text { introspective; intellectually } \\
\text { sceptical towards things that } \\
\text { are not yet proven } \\
\text { Strong ego; high self-esteem; } \\
\text { genuine interest in self- } \\
\text { understanding and } \\
\text { understanding others; } \\
\text { becoming aware of the potential } \\
\text { for self-deception; can build } \\
\text { intense and meaningful } \\
\text { relationship }\end{array}$ & $\begin{array}{l}\text { Effective listening and } \\
\text { paraphrasing without } \\
\text { unnecessary } \\
\text { interpretations; in-depth } \\
\text { questioning; identifying } \\
\text { root causes and } \\
\text { reasons of issues; } \\
\text { developing rational } \\
\text { arguments; } \\
\text { examination of } \\
\text { evidence; identifying } \\
\text { contradictions; use of } \\
\text { appropriate contracting }\end{array}$ & $\begin{array}{l}\text { Identifying motives; } \\
\text { making choices; } \\
\text { attaining goals and } \\
\text { ideals; focusing on } \\
\text { action, achievements } \\
\text { and effectiveness; } \\
\text { taking calculated risks; } \\
\text { future-oriented tasks; } \\
\text { working with self as it } \\
\text { should be }\end{array}$ \\
\hline The Acceptor & $\begin{array}{l}\text { Relativism; awareness of the } \\
\text { 'observer's' interpretation and } \\
\text { cultural conditioning; turn to } \\
\text { systems view and meaning } \\
\text { making; move from purely } \\
\text { rational analysis to more holistic } \\
\text { approach } \\
\text { Set to redefine oneself; } \\
\text { awareness of many sub- } \\
\text { personalities; explore internal } \\
\text { conflicts; scrutinise own beliefs; } \\
\text { focussed on individuality and } \\
\text { mutuality in relationship; enjoy } \\
\text { diversity; high level of empathy }\end{array}$ & $\begin{array}{l}\text { Minimal structures to } \\
\text { the process: letting } \\
\text { things unfold; exploring } \\
\text { things: they are rarely } \\
\text { what they seem; } \\
\text { working with } \\
\text { paradoxes; } \\
\text { understanding 'now' } \\
\text { rather than focusing on } \\
\text { future; spontaneous } \\
\text { interventions; accepting } \\
\text { any expression of } \\
\text { individuality }\end{array}$ & $\begin{array}{l}\text { Developing unique } \\
\text { individuality and } \\
\text { authenticity; exploring } \\
\text { role-personality match; } \\
\text { discovering the } \\
\text { meaning of critical } \\
\text { situations or specific } \\
\text { stages in life }\end{array}$ \\
\hline
\end{tabular}




\begin{tabular}{|c|c|c|c|}
\hline The Cultivator & $\begin{array}{l}\text { General systems view of reality; } \\
\text { perceive systemic patterns and } \\
\text { long-term trends; articulation of } \\
\text { own models and strategies; } \\
\text { contextualisation of problems; } \\
\text { articulate ambiguity; insightful; } \\
\text { overarching principles; truth can } \\
\text { be approximated } \\
\text { Strong autonomous self; } \\
\text { integrate all elements of the self } \\
\text { in a new meaning; the shadow } \\
\text { is accepted; aware of mutual } \\
\text { interdependency and its role in } \\
\text { individual development; } \\
\text { responsibility for relationship } \\
\text { and helping others grow }\end{array}$ & $\begin{array}{l}\text { Linking idealist vision } \\
\text { with pragmatic and } \\
\text { principled actions; } \\
\text { exploring the self; } \\
\text { coming to terms with } \\
\text { conflicting needs; } \\
\text { identifying qualitative } \\
\text { differences; } \\
\text { may be impatient with } \\
\text { slowness of the others' } \\
\text { growth }\end{array}$ & $\begin{array}{l}\text { Creating a meaningful } \\
\text { life; identifying strategic } \\
\text { concerns and } \\
\text { principles; working } \\
\text { towards self-fulfilment; } \\
\text { identifying } \\
\text { psychological causation } \\
\text { and processes; } \\
\text { nourishing creativity }\end{array}$ \\
\hline $\begin{array}{l}\text { The } \\
\text { Playwright }\end{array}$ & $\begin{array}{l}\text { Meta-cognition beyond culture } \\
\text { and own life time; cross- } \\
\text { paradigmatic; reality is } \\
\text { understood as undivided unity; } \\
\text { truth is ever illusive because all } \\
\text { thoughts are constructed and } \\
\text { language is inevitably used for } \\
\text { mapping of reality } \\
\text { The ego becomes more } \\
\text { transparent to itself and not the } \\
\text { main operator; self-critical } \\
\text { about their own ego- } \\
\text { attachments; understanding } \\
\text { others in developmental terms; } \\
\text { genuine compassion and } \\
\text { adjustment to the individual's } \\
\text { ways of meaning making }\end{array}$ & $\begin{array}{l}\text { Empathetic listening; } \\
\text { timely challenging; } \\
\text { transformational non- } \\
\text { distorted feedback; } \\
\text { drawing from } \\
\text { unconventional, non- } \\
\text { rational sources of } \\
\text { information; help in } \\
\text { reframing clients' } \\
\text { experience in terms of } \\
\text { their stage of } \\
\text { development }\end{array}$ & $\begin{array}{l}\text { Working with conflict } \\
\text { around existential } \\
\text { paradoxes; problems of } \\
\text { language and meaning } \\
\text { making; working } \\
\text { beyond contradictions } \\
\text { and paradoxes; facing } \\
\text { together the need for } \\
\text { theories and } \\
\text { explanation; creating a } \\
\text { new story of one's life }\end{array}$ \\
\hline
\end{tabular}

Table 2: Stages and Developmental Tasks for Coaching

As described in all developmental models these stages are not clear cut. They indicate only what is called a centre of gravity: where the individual draws his/her resources from. For example, a coach who is mainly 'The Questioner' may face a situation where her critical views are suspended whilst she gives emotional support to a client or when she relies on her intuition explicitly. Of course, a Questioner could, at times, move either way, reverting to Helper strategies (the stage she is just leaving) or adopting new, less familiar Acceptor strategies. As Kegan (1994, p.326) noted, individuals "gradually navigate" their evolution from one order or level to another.

The nature of work of practitioners such as coaches and coaching psychologists involves facilitating development of their clients by engaging in the processes of making meaning of personal experience, critical reflection, problem solving, exploring important existential issues, etc. The actual participation in these processes is in itself creating extensive opportunities for these practitioners in terms of enhancement of their own pace of development. Coaches are also required to and known for their dedication to continuing personal and professional development. These factors seem to contribute to their evolving cognitive capacities and influence shifts in ego- 
development. The exposure to the relevant knowledge of cognitive-developmental models and, as suggested here, potential landmarks of their development as coaches, may further enrich this process. The proposed model can be also useful for supervisors of coaches and coaching psychologists. It could focus the supervisor's attention to whether the coach is presented with an opportunity to be heard with his/her current voice or to move from a less evolved state to a more evolved state. It also adds to the recognition that the coach, as much as the coaching client, needs to be seen as a process rather than a stage.

\section{Case study}

In this case study we describe an example of coaching supervision, where both the coaching psychologist and the supervisor are aware of the developmental stages described above and have thought about how these impact on their work with coaching clients. The role of the supervisor in coaching is in supporting the coach through an adaptation and development process. The example below shows that when working with coaches in supervision an awareness of the cognitive-reflective and ego-development dimensions could be very useful.

\section{The Coach}

We follow the supervision process of a hypothetical coach, Sonia, who is familiar with the model we have outlined above and perceives herself to be at the Helper level. Sonia is happy that, in most of her coaching work, her Helper strategies serve her well; however, she has one client, Alastair, where she believes that her approach is not working.

At the outset, Sonia worked with Alastair on a specific issue involving resolution of a conflict with a member of his team. Alastair now wants to continue the coaching with Sonia, but it appears to her that he has no clear idea of what he wants to work on. Sonia has managed to develop considerable trust with Alastair and now he is beginning to share his deep uncertainties, his resistance and his doubts in relation to his working life. However, he cannot seem to make links between what he says he values and specific actions. Sonia cannot find a way of helping him to move forward and begins to feel out of her depth. She suspects that her intuitive approach is not enough to meet the needs of her client and this particular development of the coaching process. This makes her uncomfortable and so she brings the issue to supervision. She feels she needs to understand if the next level of The Questioner would be necessary to meet the needs of this client and what would she need to do if this was the case.

\section{The Coaching-Supervision Process}

Sonia's supervisor, Pat, is also familiar with the stages of development. She judges that Sonia has given appropriate support for her client in relation to the specific conflict issue. However, the problems she is presenting now seem to reflect the limitations of her current stage in relation to the client, who presents an increasingly complex array of problems.

Pat considers that Sonia's interest in the next level and intention to understand more about it is natural in relation to this particular case. Pat has noticed that Sonia is already capable of abstract thinking, making perceptive comparisons and also 
making use of her intuition. Therefore the Questioner stage seems like a natural progression for her. Indeed she seems ready to embrace the deep learning that further development of this stage will entail. Sonia has faced the limitations of her work and has already suggested that she is ready for the challenge that will inevitably need to occur to her current conceptualisation and thinking.

However, Pat is also aware of the conflict in her own role, as supervisor, between supporting the coach in using the opportunity for further development and ensuring that that the client has a best possible support. She knows that in some cases this dilemma would be extended to the issue of protecting the client. Pat has already asked herself if Sonia is the best choice of coach for Alastair at this time. However, because Sonia did so well in coaching him in relation to the initial issue, Pat believes that Sonia's concurrent further development will enhance her work with Alastair.

Pat therefore encourages Sonia to pay more detailed attention to evaluation of her own coaching practice and invites the sharing of examples from work with clients that promotes comparison. In the safety of supervision, Sonia can compare and contrast her thoughts with those of her supervisor and relevant theorists, if appropriate, in order to strengthen her critical capacity. Pat asks Sonia to identify patterns in her coaching work by cross-relating incidents. When she is encouraged to reflect in this way, Sonia reveals that she has had another client who did not seem committed to his goals, and no matter how she tried to help him, he did not seem to be able to, or want to, focus on achievement of those goals. Through exploration of the current 'unmotivated' client and reflecting back to other times when clients behaved similarly, Sonia is able to recognise a pattern, both in the two clients and in her own response to the problem. Recognition of the pattern may reveals a need for Sonia to understand 'fuzzy' goals and, rather than rely solely on her own intuition, to compare her approaches with those of relevant theorists. Such critical appraisal is indicative of The Questioner level.

In addition, Pat helps Sonia to look at issues from a number of other perspectives. She asks questions such as: "If you were supervising your own practice, what would you ask?" or "What might your client have been thinking at this moment?" or "How would this intervention be looked at from a different theoretical perspective?" This emphasis on perspective taking enables Pat to help Sonia make the move from subjective knowing with its resulting emphasis on helping, at this stage, towards a more diverse, challenging, object-oriented, questioning approach.

Pat is aware that finding opportunities to refer to and question authorities is very important in Sonia's development and so she suggests that Sonia compare different theories, explore a number of new strategies, and analyse models which develop critical understanding of coaching. She recommends to Sonia relevant material and theories of resistance that help develop her understanding in order to work with Alastair.

Pat also works to provide Sonia with confidence in her own powers of rational judgement, her ability to really critique ideas and to develop healthy scepticism in relation to the quality of evidence presented, and ultimately to develop powers of critical analysis. Pat is aware, that at the Helper level, Sonia's identity is bound up with wanting to serve others and help them and so she is careful to provide feedback in a form that compliments Sonia's current 'Helper' frame of reference, emphasising the needs of the client.

Pat notices some behaviour in Sonia that she considers as signs of progress. She notices for instance that Sonia is much more willing to question herself. She is still 
making decisions intuitively, but now asks herself why she is doing it and compares and evaluates the effectiveness of her intuitive decision. In describing a recent intervention, Sonia said "I think it worked well, but perhaps I am deceiving myself."

Sonia is also paying more attention to Alastair's motives. She is not looking at what he has achieved or not achieved, but is exploring the clarity of thinking about the meaning of particular situations for him. She asks "what does it mean to the client?" Recalling how Alastair's initial conflict was resolved satisfactorily, Sonia is making links between that event and his current dilemmas, she asks "What does having good, solid relationships with his team mean for him? and "What compromises does he seem to be able to make without losing his integrity?"

As time goes on, her relationship with Alastair has in itself become more meaningful. She has become more open and is able to acknowledge that she does not have solutions for him. She recognises that the level of issues that he is dealing with may suggest that no perfect answers can be found. He appreciated her openness about her limitations and felt more encouraged to explore his issues in depth without fear of losing face.

In addition, Pat is encouraged because Sonia has asked her to discuss whether the relationship with Alastair needs recontracting, because of the different nature of the engagement. This indicates Sonia's heightened awareness of the nature of the coaching process, its boundaries and consequences for the sponsoring organisation.

There are also some signs that indicate that the development to the Questioner is far from being complete. Pat sees that the nature of Alastair's problems, which included some bigger organisational issues, his plans for future choices and the importance of the decision he needed to make at this point in his life, need to involve him in working with his own values. However, when reflecting on some meetings with her client, Sonia is still inadvertently imposing her own interpretation on the issues. She still occasionally makes assumptions and interpretations for the client, saying things like: "In those circumstances a better course of action would be..." or "If only I could help him see this".

\section{Outcomes of the case study}

The experiences of adults are always in flux and are related to finding the right way to 'be' in the world. This was particularly evident in the issues that Alastair presented and Sonia has struggled initially to allow Alastair the reflective space to explore those issues freely. Pat however, continued supporting Sonia's reflection on this particular case. The coaching came to a natural conclusion with Alastair, when the contract with the organisation ended, and both thought that some useful outcomes had been achieved. Alastair's feedback to Sonia was that she facilitated his thinking about the team and ultimately had promoted thinking about bigger issues, which was helpful.

In relation to Sonia's supervision, Pat carried on working with her. Sonia realised that she needed to have more theoretical knowledge and undertook some continuing professional development. Her choices in terms of reading about coaching became more evidence-based and critical. She had experienced how important contracting is, and had designed her own contract, realising the importance of responding to changes in the coaching process.

\section{Conclusion}


This chapter has focused on theories of adult development. We have drawn on existing theories of cognitive development and ego development in order to present a model of levels of coach development.. We believe that the role of educators, supervisors and coaches is to understand and nurture natural progression of individual capacities along the cognitive-developmental and ego-development dimensions.

This approach does not imply specific tools and techniques. It implies careful consideration of the appropriateness of all tools and techniques that other approaches might offer to each level of development of clients as well as coaches. It is an artful balance of support and challenge appropriate for each stage of development that makes a difference in the work of a developmentally-minded practitioner. We also believe that the best way of supporting this process of natural development is an active engagement of all skills and abilities of the coach in the process of addressing the work and life tasks of their clients. Finally this approach, in terms of its application, emphasises the importance of the personal growth of practitioners themselves. It is the development of the coach as a person, rather than the application of particular techniques or methods, that makes a difference in coaching practice.

\section{Application to Other Contexts}

The cognitive-developmental approach has the same, if not higher, relevance when considered in relation to adolescence and even younger children when coached. It also has relevance to the leadership context as highlighted by Day et al (2012). Our model, however, presents the development of adult coaches and coaching psychologists only. In relation to group processes, it is very clear why group work is sometimes incredibly difficult: when individuals with different levels of development are intensely involved in the same process the chances of serious misunderstandings are numerous. However, opportunities for expected and unexpected growth are also present and possible. This is an area for further discussion and research.

\section{$\underline{\text { References }}$}

Adams, M. (2006) Towards an Existential Phenomenological Model of Life Span Human Development, Existential Analysis, Vol. 17, No. 2 (pp. 261 - 279).

Bachkirova, T. (2011). Developmental Coaching: Working with the self, Maidenhead: Open University Press.

Bachkirova, T. (2013) Developmental coaching: Developing the Self, in J. Passmore, D. Peterson \& T. Freire (Eds) The Wiley-Blackwell Handbook of the Psychology of Coaching and Mentoring, Chichester: John Wiley and sons Ltd, pp.135-154

Bachkirova, T. (2014). Psychological Development in Adulthood and Coaching, in E. Cox, T. Bachkirova and D. Clutterbuck (Eds) (2 ed.) The Complete Handbook of Coaching, London: Sage, pp. 131-144.

Bachkirova, T. \& Cox, E. (2007). A Cognitive Developmental Approach for Coach Development, in Palmer, S \& Whybrow, A. (Eds) Handbook of Coaching Psychology: A Guide for Practitioners, London: Routledge, pp. 325-350.

Beck, D. \& Cowan, C. (1996), Spiral Dynamics, Oxford: Blackwell

Belenky, M.F., Clinchy, B.M., Golderberger, N.R., \& Tarule, J.M. (1986) Women's Ways of Knowing, New York: Basic Books.

Berger, J. and Fitzgerald, C. (2002) Leadership and Complexity of Mind: The Role of Executive Coaching in Fitzgerald, C. \& Berger, J. (Eds) Executive Coaching:

Practices \& Perspectives, Palo Alto: Davies-Black Publishing 
Berger, J. (2012) Changing on the job: Developing Leaders for a Complex World, Stanford: Stanford Business Books.

Checkland, P. (1981) Systems Thinking, Systems Practice, New York: John Wiley. Cook-Greuter, S. (2004) Making the case for developmental perspective, Industrial and Commercial Training, Vo. 36, No. 7

Cook-Greuter, S. (1999), Postatonomous ego development: its nature and measurement. Doctoral dissertation. Cambridge, MA: Harvard Graduate School of Education

Commons, M. L. \& Richards, F. A. (2002) Four postformal stages. In J. Demick (Ed.), Handbook of adult development, (pp.199-219). New York: Kluwer Academic/Plenum.

Csikszentmihalyi, M. (1994) The Evolving Self: A Psychology for the Third Millennium, New York: Harper Perennial.

Day, D. V., Harrison, M. M., \& Halpin, S. M. (2012). An integrative approach to leader development: Connecting adult development, identity, and expertise. London:

Routledge.

Dewey, J. (1991) How We Think, New York: Prometheus Books.

Drath, W. (1990) Managerial strengths and weaknesses as functions of the

development of personal meaning, Journal of Applied Behavioural Science, 26, no. 4, pp 483-499

Fitzgerald, C. \& Berger, J. (2002) Leadership and Complexity of Mind: The Role of Executive Coaching in Fitzgerald, C. \& Berger, J. (Eds) Executive Coaching:

Practices \& Perspectives, Palo Alto: Davies-Black Publishing

Graves, C. (1970) Levels of Existence: An Open system Theory of Values, Journal of Humanistic Psychology, November.

Gowan, J.C. (1972) Development of the Psychedelic Individual (Chapter 6), RR

Hillman, J. (1983) Healing fiction, Barrytown, N.Y.: Station Hill Press

Kegan, R. (1994) In Over Our Heads, London: Harvard University Press.

Kegan, R. (1982) The Evolving Self: Problem and Process in Human Development,

London: Harvard University Press

King, P. M., \& Kitchener, K. S. (1994). Developing reflective judgment:

Understanding and promoting intellectual growth and critical thinking in adolescents and adults. San Francisco: Jossey-Bass.

Krishnamurti, J. (1991) Commentaries on Living: Third Series, London: Victor

Gollancz Ltd

Krishnamurti, J. (1994), (9th ed), Commentaries on Living: First Series, London: The Theosophical Publishing House

Knapp, also available at http://www.csun.edu/edpsy/Gowan/contentp.html (accessed 12 January 2007)

Kohlberg, L. (1969) Stages in the development of moral thought and action, New York: Holt, Reinhart and Winston.

Koplowitz H. (1984) A projection beyond Piaget's formal-operations stage: a general system stage and a unitary stage. In M. Commons, F. Richards and C. Armon, (eds), Beyond Formal Operations: late adolescent and adult cognitive development, New York: Praeger.

Lahey, L., Souvaine, E., Kegan, R., Goodman, R., Felix, S. (1988), A Guide To The Subject-Object Interview: Its Administration And Interpretation, Cambridge, MA: Harvard University, Graduate School of Education, Laboratory of Human Development.

Lind, R. (2000) The Seeking Self: The Quest for Self Improvement \& the Creation of Personal Suffering, Michigan: Phanes Press

Loevinger, J. (1976) Ego Development: conceptions and theories, San Francisco: Jossey-Bass

Loevinger, J. (1987), Paradigms of Personality, New York: M.H.Freeman and

Company 
Mezirow, J. and Associates (1990) Fostering Critical Reflection in Adulthood, San Francisco: Jossey-Bass.

Miller, I. (2012). A Retrospective Commentary on the Consciousness Mapping of John C. Gowan Part I. Journal of Consciousness Exploration \& Research, 3(8), 965979.

Packer, M. J. \& Tappan, M. B. (Eds.) (2001) Cultural and Critical Perspectives on Human Development SUNY Press, 2001

Perls, F. (1992), Gestalt therapy verbatim, Gestalt Journal Press

Perry, W.G. (1970) Forms of Intellectual and Ethical Development in the College Years, New York: Holt, Rinehart and Winston, Inc.

Piaget, J. (1976) The Psychology of Intelligence, New Jersey: Littlefield, Adams \& Co. Rooke, D. \& Torbert, W. (2005) Seven Transformation of Leadership, Harvard Business Review, April 2005

Sullivan, C., Grant, M. \& Grant, J. (1957) The development of interpersonal maturity: Application to delinquency, Psychiatry, 20, 373-385.

Torbert, W. (1991), The Power of Balance, Newbury Park, CA: Sage

Torbert, W. et al. (2004) Action Inquiry: The Secret of Timely and Transforming Leadership, San Francisco, CA: Berret-Koehler Publishers, Inc.

Wade, J. (1996) Changes of Mind: A Holonomic Theory of the Evolution of Consciousness, Albany: State University of New Your Press

Werner, H. (1948) Comparative Psychology of Mental Development. New York: International Universities Press.

Wilber, K. (2000) Integral Psychology, London: Shambala

Wilber, K. (2006) Integral Spirituality, Boston \& London: Integral Books

\section{Discussion points}

- If the client is more advanced than the coach, what could be seen as problematic in their work together apart from the potential lack of progress and mutual frustration?

- The cognitive-developmental approach implies the need to make a judgement about the level of development that a client or coach represents in their behaviour. This is often related to the values that individuals hold. How does it fit with a traditional view of coaching as non-judgemental?

- A number of the developmental theories quite explicitly state that the higher stages of development indicate the 'mastery of wisdom and spirituality' (Csikszentmihalyi, 1994). How compatible is this view of individual development with your vision of what coaching is about?

- What do you see as the main obstacles for the cognitive-developmental approach becoming more influential in coaching psychology than it is now?

\section{Suggested reading}

Bachkirova, T. (2011). Developmental Coaching: Working with the self, Maidenhead: Open University Press.

Berger, J. (2012) Changing on the job: Developing Leaders for a Complex World, Stanford: Stanford Business Books.

Cook-Greuter, S. (2004) Making the case for developmental perspective. Industrial and Commercial Training, 36(7): 275-281.

Kegan, R. (1994) In Over our Heads. London: Harvard University Press. 